\title{
19 How Context Shapes the Character of Cooperative Social Enterprises
}

\author{
Insights from Various Countries
}

\author{
Nicole Göler von Ravensburg, \\ Richard Lang, Simone Poledrini and \\ Marzena Starnawska
}

\section{Introduction}

The question why social enterprises (SEs) adopt particular governance structures and legal forms is tremendously complex (Ebrahim et al. 2014), and the state of literature on the institutional choice and comparative advantages of the cooperative form is still somewhat poor in several respects. The identification of critical factors determining the attractiveness and relative performance of cooperative social enterprises (CSEs) has remained national and largely monodisciplinary. The approaches adopted by existing comparative analyses so far belong in most cases to the fields of legal studies (Fici 2015), political economy (e.g., Ostrom) or business economics (e.g., Borzaga et al. 2017). These perspectives frequently relate closely to certain schools of economic, political or legal thought (e.g., canonical rational-choice theory, social- and solidarity-economy thinking or liberalism). Empirically based international discussions are rare, since it is difficult to capture the variety of CSEs in their current and historical institutional contexts (see inter alia Teasdale 2011 and Kerlin 2010). Epistemologically, such research should be based on an international comparison and go beyond hermeneutics.

The ICSEM Project offers the possibility for such a non-normative understanding of the prevalence of CSE. By way of a meta-analysis of national ICSEM "country papers"1 (to which we refer henceforth by the acronym CPs) from Europe, North America and Australia, ${ }^{2}$ this chapter tackles the following question: "Which elements of the institutional context shape the characteristics of CSE?". It aims to generate preliminary propositions about how contextual elements interact with certain characteristics of CSE, and how such contextual elements might influence the choice of the cooperative form. Based on such analysis, it puts forward several hypotheses about the relative importance of various contextual elements.

Section 19.1 of this contribution clarifies how we dealt with terminological issues and sketches our inductive methodological approach.

DOI: $10.4324 / 9780429055140-19-22$ 
The developed methodology and analytical framework represent the results of the first phase of our research; they are explained partly in section 19.2 and-for the sake of brevity and on account of their close relationship with the research results-partly in section 19.3 . Section 19.3 presents the results of our second research phase, namely the possible patterns that can be identified in the interplay of contextual factors and CSEs' characteristics. The findings are subject to a critical discussion in the conclusion.

\subsection{Terminological and Methodological Approach}

Rather than relying on a normative definition of social enterprise, the CPs in the ICSEM Project are based on the EMES conceptual approach to social enterprise. This conceptual approach includes three sets of indicators-namely economic, social and governance-related indicators (Defourny and Nyssens 2012: 12-15). These are not criteria to be met in order to deserve an "SE label"; they rather help to characterise groups or categories of social enterprises relative to one another.

This relatively open delineation left CPs' authors with sufficient room to accommodate national perceptions, which represents a good precondition for a non-normative comparative analysis. The same is true for national authors' use of the term "cooperative". From the initial analysis of the CPs, it became clear that the term was mostly used in relation to what national laws and traditions consider as a cooperative. Again, we accepted this for the purpose of our study, even though we are well aware that the essence of cooperative organisation can be found in other legal forms as well, and even in some unincorporated organisations.

In order to avoid normative preconceptions, we followed a strictly inductive process. As underlined above, since the method and results are closely intertwined in such an approach, both are described together in section 19.2 and section 19.3.

Fifteen ICSEM CPs from various countries-namely Canada, France, Germany, Switzerland and the US (with two CPs each) and Australia, Austria, Belgium, Israel and Poland (with one CP each) - had been published by December 31, 2016 and all of them mentioned CSE. Three more papers—on Hungary, Italy and Spain—-that were then in draft stage but almost finalised were made available to us by their authors. It was decided to include these additional papers to enrich the sample, which finally included eighteen CPs.

\subsection{Development of an Analytical Framework}

In order to develop an analytical framework (phase one of the research process), we went through a three-step screening process. This allowed us to identify important contextual factors and CSE's characteristics. 


\subsubsection{Screening Process to Identify Distinctive Dimensions and Variants}

In the first step of developing the analytical framework, all eighteen CPs were screened for the perspectives they offered on CSE. In a qualitative content analysis of the dataset, we identified sections in each CP dealing with the phenomenon of CSE and derived specific perspectives and arguments that national authors thought crucial to the conceptualisation of CSE in their respective context (i.e., at the national level, except for the province of Quebec). We identified five clusters of perspectives:

- wide historical context and cooperative-specific development "paths", including embeddedness in the economic system, company and nonprofit organisation (NPO) law, tax law and institutionalised supervision (Huybrechts et al. 2016);

- CSE in different conceptualisations of societal transformation (from at least three perspectives: cooperative movement, state, non-profit/ common-good sector);

- fields of CSEs' activities/sectors in comparison to social enterprise in general and to institutionalised cooperative sectors;

- role of policies and institutions linking social capital across different societal sectors (e.g., public bodies, philanthropists, private corporate investors, etc.), effective at different spatial scales;

- type of CSE governance.

In the second step, to assess the relevance of the various perspectives identified, all eighteen CPs were analysed to determine which perspectives were shared by more than a third of them. This was the case for the contextual factors outlined in section 19.2.2 and CSEs' characteristics outlined in section 19.2.3. These interim results were suitable to serve as dimensions for the cross-country comparative analysis focusing on the interplay between contextual factors, on the one hand, and characteristics of CSE, on the other hand. Only twelve out of the eighteen papers, however, referred to all the selected dimensions in some depth. So, it was decided to continue the analysis with only these twelve CPs-on Australia, Austria, Belgium, Canada, France, Germany, Hungary, Italy, Poland, Spain, Switzerland and the US.

In the third step of the screening process, these twelve CPs were examined in order to identify variants for each of the dimensions identified. Through an inductive process again, between four and six variants were defined for each dimension. The content of these variants is explained in section 19.3. We decided to follow up on those variants that were present in more than three CPs, so only these have been included in the final analytical framework. 


\subsubsection{Contextual Factors Identified}

Six contextual factors were present in more than a third of the eighteen CPs selected in the first step of phase 1 .

- Nearly all CPs' authors focused, in their accounts of CSE, on historical developments. A range of CPs made clear reference to historical trajectories of the whole socio-economic system in the country, highlighting the links between such contexts and the cooperative sector's organisational models, including CSE.

- Another frequent focus was on the emergence of new social movements. CSEs often seem to emerge in response to socioeconomic crises, for example, to meet the resulting demands for social services and solve unemployment problems, or they aim to promote a "green" sustainability agenda through ecological living.

- Legal provisions for cooperatives often determine CSE activities. Some countries have developed a specific legal framework to regulate the phenomenon of CSE and/or to facilitate its development and stimulate its growth; such a development has been observed in Italy (Poledrini 2015), Poland (Piechowski 2010), France (Hiez 2013) and Hungary (European Commission 2014d) with the creation of the legal form of "social cooperative"; in Spain, with the "social-initiative cooperative" (CIS) legal form; and in the province of Quebec, in Canada, with the "solidarity cooperative" legal form.

- Intermediaries link cooperative organisations and their members to actors in the institutional environment (e.g., government bodies, banks, institutional investors) through lobbying or as regulators of the cooperative sector. These intermediary bodies can also be federations; secondary cooperatives; national, regional or local umbrella organisations (including social enterprises); and research institutions.

- Social-economy-related policies are at the basis of the emergence of CSE especially in Spain, France, Hungary and Poland, ${ }^{3}$ while in other countries, CSE development is influenced by broader social or regional policies. More precisely, the social-economy approach is firmly based on the belief that isomorphism can only be avoided by favouring participatory governance and limited profit distribution (Fici 2015: 26). Consequently, legal provisions to ensure the protection of these features are usually central in the countries where the social-economy approach is important; this is the case for many romance-language countries, as illustrated for example by the French "collective-interest cooperative". By contrast, in North America, Australia, Germany, Austria or Switzerland, the concept of social economy has never, or only very recently, been associated with the concept of cooperatives. 
- Nearly all CPs' authors report that alternative legal forms to the cooperative one do exist in their respective countries/region.

\subsubsection{CSE's Characteristics Identified}

Regarding the characteristics of CSEs, the following eight features were found to be central by most CP authors:

- Autonomy: Two aspects of autonomy can be distinguished. Political autonomy (or autonomy in terms of governance) refers to the influence of political decision-makers and interests on the strategic development of the CSE. A second aspect, namely that of financial autonomy, refers to those situations where (social) policies and subsidies are not vital for the CSE and a diversity of contract partners exists.

- Membership composition: CSE membership composition can be homogenous and/or heterogeneous. Homogenous membership refers to the situation where all members share common interests. By contrast, in organisations with heterogeneous membership, there are different subgroups, with divergent interests. The CPs analysed further suggest to distinguish two major forms of heterogeneous membership: (1) with two subgroups, as for example in credit cooperatives; and (2) with multiple subgroups, as in multi-stakeholder cooperatives, where the different subgroups have at least one common interest but also diverging interests.

- Types of goods and services: Data from the CPs reveal that CSEs provide various kinds of goods and services. Indeed, they can provide private goods, when they address only their members' needs, such as in agriculture, or they can provide public or merit goods, when they generate benefits for non-members. Goods and services can be of a collective type (common goods) or of an individual one (personal services).

- Main source of revenue: Our analysis showed two main sources of revenue for CSEs, namely (market) sales, including sales to government bodies, on the one hand, and public subsidies and grants, on the other hand. From the initial cross-country comparison, we can hypothesise that CSEs are more dependent on sales in liberal market contexts (e.g., the US; see Cooney 2015) than in traditional welfare and corporatist state contexts (e.g., Germany; see Birkhölzer et al. 2015).

- Predominant fields of activity: Across the different countries analysed, three predominant fields of CSE activity can be identified: work integration, personal services (e.g., child care) and local/regional infrastructure development (cooperatives providing public or proximity services).

- Types of benefits/beneficiaries: Another dimension (linked to others) refers to the main benefits that CSEs provide or the main 
beneficiaries that they serve. Based on our analysis, we can distinguish three main categories of benefits/beneficiaries: provision of employment for members; servicing members (hereby leading to indirect benefits for members); and servicing wider groups of beneficiaries, including non-members.

- Participatory character of the governance: Our analysis of CPs suggests three variants: the board can include only members; the board can include (non-member) beneficiaries; there is a possibility for external stakeholders to be part of the board.

- Profit distribution: The dimension of profit distribution can be categorised in the following way: profit distribution can be prohibited or regulated by law; or it can be decided by the members; or there are no restrictions at all.

\subsection{Identifying Interactions Between Contextual Factors and CSEs' Characteristics}

The second phase of our analysis presented us with the challenge of having to identify unambiguous relationships between contextual factors and CSEs' characteristics. The matrix shown in table 19.1 resulted from the steps outlined above. It is both a first finding of our inductive approach and an analytical framework for the next step of analysis. Final findings are presented in more detail in sections 19.3.2 to 19.3.4, where each subsection corresponds to a contextual dimension. The numbering of cells in table 19.1 alludes to the sequence in which findings are covered in sections 19.3.2 to 19.3.4. An additional perspective in our analysis concerned the link between the various contextual dimensions, on the one hand, and the choice of the cooperative form by social enterprises, on the other hand. Whenever elements about this perspective appeared relevant, we included them in the following subsections.

\subsubsection{Overview of Interactions Identified}

Table 19.1 outlines all interactions between contextual factors and CSE's characteristics considered relevant in the CPs. The numbered fields indicate where the CPs gave sufficiently precise information about the relationships for further comparison and conclusions. Where fields are left unnumbered, this was not the case and more research is needed. This is particularly the case with regard to the manifold interactions between two contextual dimensions, namely "historical developments" and "new social movements", on the one hand, and CSEs' characteristics, on the other hand. Although the role of intermediaries was highlighted in several CPs, there was not sufficiently concrete information either about how these intermediaries (cooperative federations or agencies specialised in the promotion of SE) interact with CSEs' characteristics. 
322 Göler von Ravensburg, Lang et al.

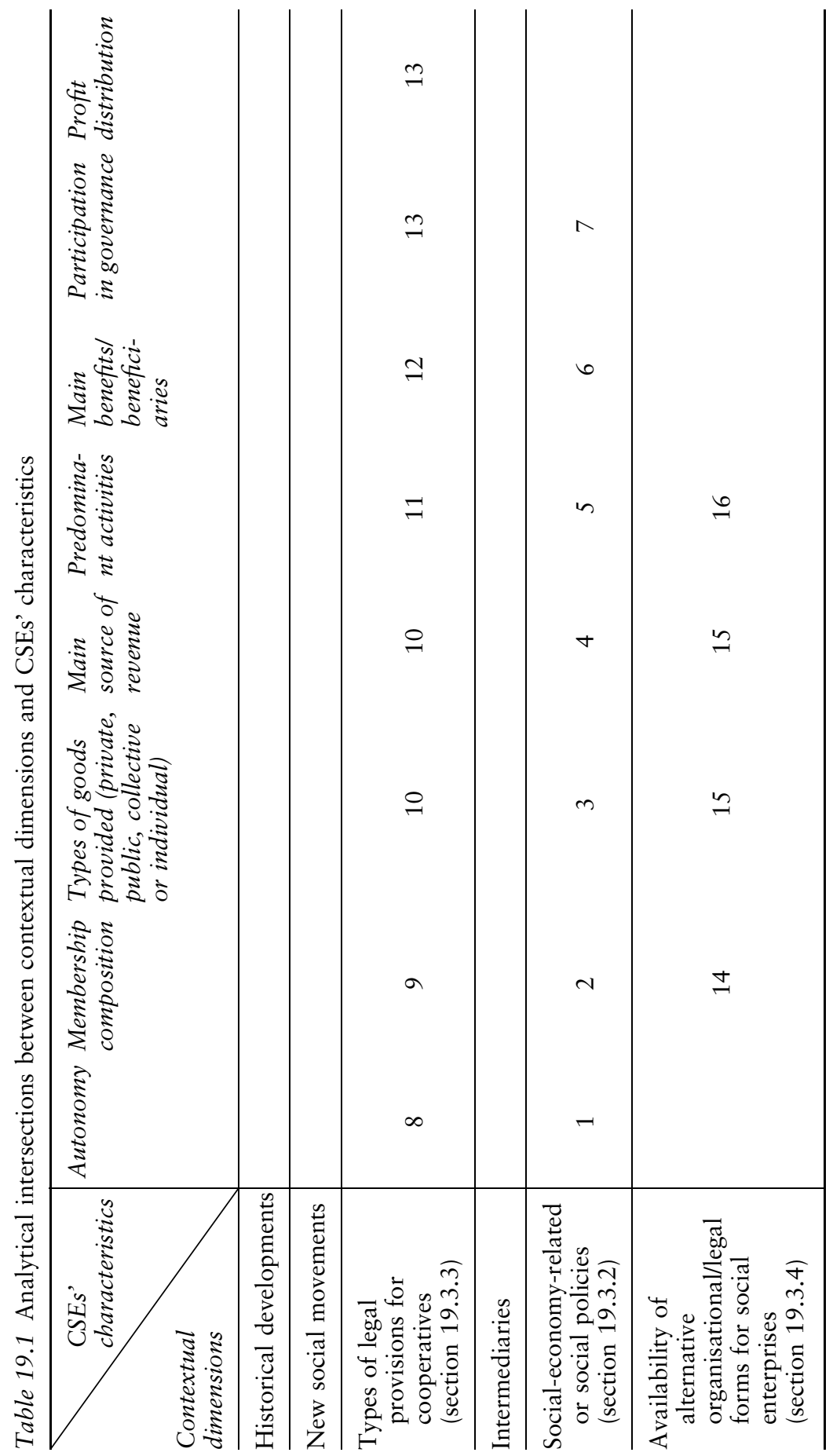




\subsubsection{Interplay Between Social-Economy-Related/Social Policies and CSEs' Characteristics}

The CPs suggest that national, regional, local and sectoral socioeconomic policies do affect social enterprise in general and CSE in particular. While comprehensive national social-economy-related policies exist in Spain, France, Hungary and Poland (Katona 2014; KPRES 2014) and regional ones in the Quebec province in Canada and in Belgium, socio-economic policy measures in Italy, Germany, most of Switzerland, the US and Australia are less general and more issue related. Since literature differentiates these two approaches, we tried to identify interplay mechanisms for each. However, both use various combinations of subsidies and contracts for the provision of public goods and services. Some also entail specific laws governing social enterprise. Thus, on the functional level, we could frequently not differentiate between socialeconomy-related policies and more general social policies; the sample was also too small to do so. We indicated where differentiation was possible, such as in point (6), but overall, we thus confined our analysis to the question of whether socio-economic policies of any kind influenced the central characteristics of CSEs that we had identified. We elaborate on this in detail in the following list, numbering the paragraphs in accordance with the numbering in table 19.1.

1. Our analysis does not support the assumption that public policies would automatically limit the organisations' autonomy. However, the CPs indicate potential limitations of cooperative autonomy due to the representation of public bodies in the governance structure of CSEs in eight countries. In several countries, where CSEs are providing public services governed by social policies, these influence CSEs' production processes. Overall, in all the countries analysed, CSEs seem geared towards achieving financial autonomy by generating at least substantial parts of their turnover from sales. Public policies at times influence this, as do other factors, such as legal barriers to market participation by social enterprises.

2. There does not seem to be a link between public policies and the membership composition of CSEs. While France and Spain-two countries with well-developed social-economy policies-favour multistakeholder CSEs, these also seem to gain popularity in countries without central social-economy policies (e.g., Italy), and multistakeholder CSEs do not exist in Poland and Hungary, despite these countries having a central social-economy policy (Piechowski 2010).

3. CSEs can provide private as well as merit and public goods. Naturally, social-economy policies (e.g., in France or Belgium) as well as socio-economic policies (e.g., housing policy in Austria and Australia) or sector policies (e.g., energy in Germany) aim at the 
production of public and merit goods. CSEs in countries without such policies are also found to produce public goods, but most likely to a lesser extent.

4. As for the main source of revenue of CSEs, there are some hints in the CPs that countries with socio-economic policies to support social enterprise (and particularly with local or regional programmes) are precisely those where CSEs can generate revenue (grants and sales revenues) from public sources. However, except in the case of Italy (Borzaga et al. 2017 and Poledrini 2018), the available data are not strong enough to support a suggestion that the choice of legal form depends on socio-economic policies entailing public support.

5. The link between predominant activities and socio-economic policies remains fuzzy. For example, the work-integration sector is a sector generally strongly dominated by social policy and encompassing many social enterprises. Yet, CSEs do not occur in greater numbers in this sector than in other personal services in nine of the twelve countries analysed. Furthermore, in the German-speaking countries (Austria, Switzerland and Germany) with well-established social policies for work integration, work-integration social enterprises (WISEs) hardly seem to operate in a cooperative form. In other sectors, the existence of socio-economic policies does not seem to be a precondition for the existence of worker cooperatives or cooperative service providers. At the same time, significant numbers of CSEs for local or regional infrastructure development seem to emerge without any or with minor policy-related support in some countries, including the German-speaking ones and Belgium. And a clear link can be seen between certain sector policies and the emergence of CSEs, such as in housing in Austria (Anastasiadis and Lang 2016), and energy, leisure and retail in less densely populated areas in Germany (Blome-Drees et al. 2016).

6. Data from the CPs clearly suggest a link between social-economyrelated policies-as distinct from other socio-economic policies-and the recognition of certain groups of main beneficiaries within CSEs, for example, disabled people. All countries with social-economyrelated policies see CSEs as organisations addressing both the employment and service needs of members and non-members. By contrast, most countries without such policies-including Australia, the English-speaking part of Canada and the German-speaking countries-firmly see CSEs as organisations primarily benefitting their members.

7. Participation of non-members in governance is possible in countries with and without national socio-economic policies. An example of the latter is the US, where many state laws allow government agencies and their representatives to be involved in the governance of CSEs. They can even be owners in purchasing cooperatives or shared-services 
cooperatives; public representatives can also generally be directors of cooperatives in some states. However, the literature at hand does not help to estimate how frequently this legislation is applied.

\subsubsection{Interplay Between Legal Provisions Regulating Cooperatives and Characteristics of CSEs}

Eight countries in our sample have cooperative legislation at the national level, with (e.g., in France) or without (e.g., in Germany) additional sectoral cooperative laws. In three countries, legislation on cooperatives is the responsibility of provinces and federated states (Canada, the US and Australia). Albeit to a different extent, France, Italy and Poland are relying on sectoral cooperative legislation. To fully understand the interplay of legal provisions on cooperatives with CSEs' characteristics, it should be mentioned that, in some countries, a special "social-purpose" qualification was created for companies that want to underline their social aim. Depending on the criteria applicable, this can shape the character of social enterprise towards cooperative-like characteristics. An example is Belgium, where companies applying for such a qualification were first allowed to operate under any company legal form, but the criteria to be met in order to obtain the "social-purpose" qualification influenced the applying enterprises in a cooperative way. Since 2019, this legislation has changed and the cooperative is now the only legal form that may be combined with a "social-enterprise" qualification. ${ }^{4}$

8. The financial autonomy of CSEs seems generally high in our sample of high-income countries. Indications regarding possible limitations of this autonomy are rather connected to the representation of nonmembers, and especially of state representatives, on the boards of CSEs. In Poland, for instance, the law allows public agencies to become board members; they thus become part of the governance structure of CSEs. In some CPs, the presence of state representatives on the boards of CSEs is reported as related to an economic and cooperative history marked by disruption, and it is considered to have a significant influence on current decision-making processes within CSEs (Fekete et al. 2017). However, state representation on boards also occurs in several countries with a "continuous" cooperative history. For instance, the French collective-interest cooperative (société coopérative d'intérêt collectif, or SCIC) is subject to more public control than any other type of cooperative (Hiez 2013: 401). Similar observation has been made in some states in the US and provinces in Canada. There, it can be traced back to CSEs being involved in public (health) programmes. Yet none of the corresponding CPs report any challenges in autonomy. 
9. As far as membership composition is concerned, cooperative legislation in the countries studied seems to be based on open and voluntary membership and on members being the main beneficiaries. These findings concur with the principles of the International Cooperative Alliance (ICA). Yet, it also appears that wherever CSEs are the focus of social-economy-related policies (rather than of more general socio-economic policies), national or provincial legislation on cooperatives often stipulates that membership ought to include more than one interest group. For instance, French collective-interest cooperatives $(\mathrm{SCICs})^{5}$ are multiple-stakeholder organisations with governance by several possible "colleges" (of employees, users, volunteers, local authorities etc); any physical or legal person who contributes to the activity can belong to one of these colleges. SCICs seem to have been modelled on the Italian social cooperatives (Hiez 2013: 400), which encompass similar multi-stakeholder governance.

10. The types of goods provided and the main source of revenue of organisations are usually linked, to the extent that grants and subsidies are means to publicly finance collective goods, while sales are often linked to individual goods and services, be they purchased by private or public customers. Consequently, we decided to present the findings about the interlink of both these aspects with the occurrence of certain legal forms and in particular the cooperative one together. CPs suggest that grants, whether public or private, seem a great deal less important in CSEs' revenue mix than sales. As regards the difference between public and private individual goods, only the Italian and French CPs suggest that the way in which company law, cooperative law or SE-specific laws regulate the functioning of CSE strongly determines whether CSEs deliver public and/or private goods.

11. Looking at what CPs report on the interaction between national patterns or types of cooperative legislation and CSEs' predominant activities, it becomes apparent that sectoral cooperative legislation frequently aims at sectoral activities such as work integration, agriculture or housing. French cooperative legislation is a prime example of this. At the same time as describing activities, such legislation usually also entails criteria for cooperative membership. Meanwhile, national cooperative legislation covering all sectors at once usually makes, at some point, special provisions for certain activities such as banking (see e.g., the German Genossenschaftsgesetz), or it is complemented by special acts (as e.g., in Poland) (Piechowski 2013). Additional literature suggests that, whenever national cooperative laws do not explicitly provide for the existence of a form of social-purpose cooperative, social enterprises are less likely to adopt the cooperative form. 
12. When analysing the main benefit/main beneficiaries of CSEs, we should first keep in mind that the traditional picture of cooperatives benefitting their members appears dominant. In general, a focus on members is of course present in consumer and agricultural cooperatives in many countries. The CPs analysed mostly discuss workers' cooperatives and CSEs providing (social) services (e.g., care for handicapped people, child care, etc.) - that is, fields which are not typical of member-focused cooperatives. However, cooperative legislation does not make special provisions for such activities in all the countries surveyed-it does not make such provisions, for example, in Austria, Switzerland and certain provinces of Canada and Australia, where CSEs providing social services are not as widespread. However, CSEs of this type seem to be currently gaining ground, particularly in cases where common-pool resources tend to become neglected (see, e.g., the development of Swiss alpine-pasture cooperatives) or where social infrastructure is difficult to maintain on account of low population densities, as in the US or Germany (Blome-Drees et al. 2016: 102-103).

\subsubsection{Interplay Between the Availability of Alternative Legal Forms for Social Entrepreneurship and Main Characteristics of CSE}

Phase 1 results suggested there could be interrelations between the availability of alternative legal forms, on the one hand, and the membership composition, goods provided/main revenue sources and the predominant activities of CSE, on the other hand.

14. Our analysis of the CPs reveals that, in virtually all the countries studied, SEs can adopt more than one legal form. In regard to membership composition, the cooperative form is usually chosen where the solution to a social problem requires people with different interests to come together (e.g., buyers, sellers and workers)—which seems to become increasingly frequent. However, this observation does not necessarily point to a comparative advantage of the cooperative form over other legal forms. Corroborating such hypothesis would require a comparison with the development of SEs under other legal forms, as well as a comparison between countries where the law provides for the existence of multi-stakeholder cooperatives and countries where it does not. Still, the indication that a link might indeed exist between the legal existence of multi-stakeholder cooperatives and the share of SEs using the cooperative form should be taken seriously. This contextual factor might prove just as strong, in terms of influence, as SE policies.

15. The majority of CSEs in all the countries analysed produce private goods and services, and obtain most of their revenues from sales, 
regardless of whether or not alternative company forms can be used to organise SE activities. At the same time, the examples of Belgium and France suggest that a link might exist between the production of public goods and SEs using a cooperative form. In the US, Quebec, Germany, Austria, Switzerland, Hungary and Poland (Ministry of Family, Labour and Social Policy 2016), only a minority of CSEs provide public goods. At least for Austria and Germany, this can be attributed to national traditions: in these countries, other forms of organisations-namely not-for-profit associations-have traditionally been providing public goods for a long time (see, e.g., Heitzmann and Simsa 2004, as quoted by European Commission 2014a: 25). There are indications, for example from Germany, though, that a cooperatively organised provision of certain public goods might become more attractive, despite the existence of organisational alternatives. The evidence in the CPs is too scant, however, to come to any firm conclusions in this regard.

16. Whether the availability of alternative legal forms interrelates with the predominant activities of CSEs cannot be answered equally for all countries. In nine of the analysed countries, WISEs and SEs providing personal services are frequently organised in a cooperative form. Quite a different picture presents itself in Austria, Germany and Switzerland. In Austria and Germany, WISEs usually adopt the form of a (public-benefit) limited-liability company (European Commission 2014a: 6, 30 and European Commission 2014b: 35-36). In Switzerland, WISEs are usually organised as associations or foundations (European Commission 2014c: i). There are slightly more CSEs in Austria and Germany in the field of personal-services provision, while there does not seem to be any CSEs operating in this field of activity in Switzerland. However, in all three countries, there is a trend towards the emergence of CSEs for the maintenance of local or regional social infrastructure (Gonin and Gachet 2015: 31; Anastasiadis and Lang 2016: 15; Stappel 2017: 151-153).

This last observation points to two more general analytical results. First, considering the sum of interactions between this last contextual dimension and CSEs' characteristics, it becomes obvious that there appear to be interactions between this contextual dimension and other contextual dimensions. And secondly, there are indications that the reasons to choose specific legal forms to suit a certain membership composition or conduct certain activities are most likely closely linked with socioeconomic policies, traditional welfare delivery structures and certain legal provisions for the cooperative form, rather than with the influence of sectoral cooperative and non-cooperative intermediaries and certain institutional path dependencies. 


\section{Conclusion}

Despite certain methodological constraints and the limited comparability of country data, our analysis provides some findings about the interplay between context and CSEs' characteristics, and resulting trends. Overall, the analysis shows that CSE is a very context-specific phenomenon.

The state appears to be a key enabler of CSE in many countries, for example through specific legislation and funding streams. Recent examples can be found in the fields of renewable energy, resident-led housing or public-service delivery. There seems to be a trend towards the emergence of CSEs across many countries in general, and of cooperative initiatives aimed at managing common-pool resources as well as local and regional infrastructure in particular.

While there are specific policies for social enterprise in some countries, social and economic policies at large also have an influence on the CSE sector. Our findings also suggest a dominance of WISEs in particular among CSEs; such dominance appears to clearly relate to broad socioeconomic policies and not to specific cooperative policies/legislation. The above findings generally support results of previous, mainly qualitative and hermeneutic, studies.

In line with the DNA of strong cooperative movements, CSEs primarily serve their members' interests, and their "concern for the community" currently remains a secondary goal in most cases. At the same time, our findings clearly show that it is their orientation towards the community that distinguishes CSEs from other cooperative-type enterprises. Indeed, CSEs also serve non-members, and even whole communities of place or of interest. They do so more easily with external assistance, but also manage without it.

Notably, what we found in our cross-country study is that CSEs exist virtually everywhere, and that they are private entities, mainly providing private goods and services. Most of their revenue is generated by sales, regardless of their legal form. In fact, the specific legal form for CSEs still varies among the countries studied. Furthermore, CSEs are almost inevitably discussed in conjunction with traditional cooperative sectors. They are characterised by pronounced financial autonomy, which is not necessarily limited by the socio-economic policies supporting them. The most prominent CSE-related policy is definitely the Italian social-cooperative one, which has influenced social-economy-related policies in several Central and Eastern European countries. The possibility to include several interest groups into the membership might be a driving force for the future growth of CSE in most countries. 


\section{Notes}

1 All ICSEM Working Papers-that is, both "country papers" and "transversal papers"-are available online on the ICSEM Project's website: http:// www.iap-socent.be/icsem-working-papers.

2 The ICSEM Project generated a set of "country papers" also covering Australia, Canada, Israel, New Zealand, the United Arab Emirates, the United States, Rwanda and South Africa, which did not fit into the "regional approach" adopted for the four ICSEM books. Most of these country papers were published in a special issue of the Social Enterprise Journal, edited by Defourny and Nyssens (2017); some were also included in transversal thematic analyses, as it is the case here.

3 For a wider and deeper analysis of the role of social-economy-related policies, see chapter 16 in this volume.

4 For more details, see chapter 1, devoted to Belgium, in this volume.

5 It has to be noted, though, that SCICs constitute some kind of exception in France (Hiez, 2013: 397), where most types of cooperatives are restricted to servicing their members only.

\section{References}

Anastasiadis, M. \& Lang, R. (2016) "Social enterprise in Austria: A contextual approach to understand an ambiguous concept", ICSEM Working Papers, No. 26, Liege: The International Comparative Social Enterprise Models (ICSEM) Project.

Birkhölzer, K., Göler von Ravensburg, N., Glänzel, G., Lautermann, C. \& Mildenberger, G. (2015) "Social enterprise in Germany: Understanding concepts and context", ICSEM Working Papers, No. 14, Liege: The International Comparative Social Enterprise Models (ICSEM) Project.

Blome-Drees, J., Boggild, N., Degens, P., Michels, J., Schimmele, C. \& Werner, J. (2016) Potenziale und Hemmnisse von unternehmerischen Aktivitäten in der Rechtsform der Genossenschaft, Münster: LIT Verlag.

Borzaga, C., Poledrini, S. \& Galera, G. (2017) "Social enterprise in Italy: Typology, diffusion and characteristics", Euricse Working Papers, No. 95(17) [Also published in the series of ICSEM Working Papers, No. 44, Liege: The International Comparative Social Enterprise Models (ICSEM) Project].

Cooney, K. (2015) "Social enterprise in the United States: WISEs and other worker-focused models", ICSEM Working Papers, No. 09, Liege: The International Comparative Social Enterprise Models (ICSEM) Project.

Defourny, J. \& Nyssens, M. (2012) "The EMES approach of social enterprise in a comparative perspective", EMES Working Papers Series, No. 12/03, Liege: EMES International Research Network.

Defourny J. \& Nyssens, M. (2017) "Mapping social enterprise models: An international perspective", Social Enterprise Journal, Vol. 13, No. 4, pp. 318-442.

Ebrahim, A., Battilana, J. \& Mair, J. (2014) "The governance of social enterprises: Mission drift and accountability challenges in hybrid organizations", Research in Organizational Behavior, Vol. 34, pp. 81-100. 
European Commission (2014a) "Country Report: Austria", A Map of Social Enterprises and Their Ecosystems in Europe, Brussels: European Commission. Available HTTP: http://ec.europa.eu/social/keyDocuments.jsp?

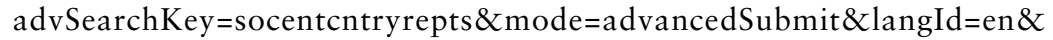
policyArea $=\&$ type $=0 \&$ country $=0$ \&year $=0$ \&orderBy $=$ docOrder $($ accessed March 27, 2017).

European Commission (2014b) "Country Report: Germany", A Map of Social Enterprises and Their Ecosystems in Europe, Brussels: European Commission. Available HTTP: http://ec.europa.eu/social/keyDocuments.jsp? pager .offset $=10 \& \&$ langId $=$ en $\&$ mode $=$ advancedSubmit $\&$ year $=0 \&$ country $=$ 0\& type $=0 \& a d v S e a r c h K e y=$ socentcntryrepts\&orderBy $=$ docOrder $\quad$ (accessed on March 27, 2017).

European Commission (2014c) “Country Report: Switzerland”, A Map of Social Enterprises and Their Ecosystems in Europe, Brussels: European Commission. Available HTTP: http://ec.europa.eu/social/keyDocuments.jsp? pager . offset $=20 \& \&$ langId $=$ en $\&$ mode $=$ advancedSubmit $\&$ year $=0 \&$ country $=$

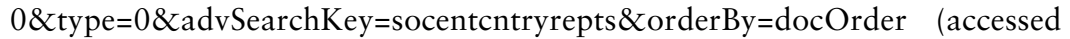
on May 1, 2017).

European Commission (2014d) "Country Report: Hungary", A Map of Social Enterprises and Their Ecosystems in Europe, Brussels: European Commission. Available HTTP: http://ec.europa.eu/social/BlobServlet?docId=13103\&langId= en (accessed on October 20, 2016).

Fekete, E. G., Hubai, L., Kiss, J. \& Mihály, M. (2017) "Social enterprise in Hungary", ICSEM Working Papers, No. 47, Liege: The International Comparative Social Enterprise Models (ICSEM) Project.

Fici, A. (2015) "Recognition and legal forms of social enterprises in Europe: A critical analysis from a comparative law perspective", Euricse Working Papers, No. 82(15).

Gonin, M. \& Gachet, N. (2015) "Social enterprise in Switzerland: An overview of existing streams, practices, and institutional structures", ICSEM Working Papers, No. 03, Liege: The International Comparative Social Enterprise Models (ICSEM) Project.

Heitzmann, K. \& Simsa, R. (2004) "From corporatist security to civil society creativity: The nonprofit sector in Austria", in Zimmer, A. \& Priller, E. (eds) Future of Civil Society. Making Central European Nonprofit Organisations Work, Wiesbaden: VS Verlag für Sozialwissenschaften, pp. 713-731.

Hiez, D. (2013) "Chapter 17 - France”, in Cracogna, D., Fici, A. \& Henrÿ, H. (eds) International Handbook of Cooperative Law, Heidelberg, New York, Dordrecht \& London: Springer, pp. 393-411.

Huybrechts, B., Defourny, J., Nyssens, M., Bauwens, T., Brolis, O., De Cuyper, P., Degavre, F., Hudon, M., Périlleux, A., Pongo, T., Rijpens, J. \& Thys, S. (2016) "Social enterprise in Belgium: A diversity of roots, models and fields", ICSEM Working Papers, No. 27, Liege: The International Comparative Social Enterprise Models (ICSEM) Project.

Katona, A. (2014) "Social cooperatives in Hungary: The engines of local development?”. Available HTTP: https://prezi.com/cav-k5tuptib/socialcooperatives-in-hungary-the-new-engines-of-local-development (accessed on November 11, 2016). 


\section{Göler von Ravensburg, Lang et al.}

Kerlin, J. A. (2010) "A comparative analysis of the global emergence of social enterprise”, Voluntas, Vol. 21, No. 2, pp. 162-179.

KPRES (2014) The National Programme for the Development of Social Economy, Ministry of Family, Labour and Social Policy, Warsaw. Available HTTP: http:// www.ekonomiaspoleczna.pl/files/wiadomosci.ngo.pl/public/korespondenci/portal_ ekonomiaspoleczna/KPRES_23.06.2014.pdf (accessed on October 15, 2014).

Ministry of Family, Labour and Social Policy (2016) Informacja o funkcjonowaniu spółdzielni socjalnych działajacych na podstawie Ustawy $z$ dnia 27 kwietnia 2006 r. o spóldzielniach socjalnych za okres 2014-2015, Warsaw: Ministry of Family, Labour and Social Policy. Available HTTP: http:// bip.kprm.gov.pl/download/75/43408/

Informacjaofunkcjonowaniuspoldzielnisocjalnych.pdf (accessed on January 10, 2017).

Piechowski, A. (2010) Raport o spótdzielczości polskiej, Warsaw: Krajowa Rada Spółdzielcza.

Piechowski, A. (2013) "Chapter 28- Poland", in Cracogna, D., Fici, A. \& Henry, H. (eds) International Handbook of Cooperative Law, Heidelberg, New York, Dordrecht \& London: Springer, pp. 609-634.

Poledrini, S. (2015) "Unconditional reciprocity and the case of Italian social cooperatives", Nonprofit and Voluntary Sector Quarterly, Vol. 44, No. 3, pp. 457-473.

Poledrini, S. (2018) "The emergence of new social enterprise models in Italy: First insights from the international ICSEM Project". Impresa Progetto Electronic Journal of Management, Vol. 2, pp. 1-19.

Stappel, M. (2017) "Zu genossenschaftlichen Neugründungen mit sozialer Zielsetzung”, in Schmale, I. \& Blome-Drees, J. (eds) Genossenschaft innovativ, Wiesbaden: Springer VS, pp. 147-160.

Teasdale, S. (2011) "What's in a name? Making sense of social enterprise discourses”, Public Policy and Administration, Vol. 27, No. 2, pp. 99-119. 